\title{
Magdalena Brodacka
}

Uniwersytet Jagielloński w Krakowie

Instytut Nauk o Człowieku w Wiedniu

(iD) http://orcid.org/0000-0001-6102-1284

\section{Kim jestem Bohumila Hrabala, czyli pytanie o tożsamość w samym sercu Europy}

\author{
Bohumil Hrabal's Who I Am, or the Question of Identity \\ in the Very Heart of Europe
}

\begin{abstract}
The article Bohumil Hrabal's "Who I Am," or the Question of Identity in the Very Heart of Europe, is an attempt to place Hrabal's work in the autobiographical current of his prose. At the same time, it is a deconstruction of the writer's biographical legend by renaming and defining the linguistic procedures and metaphors used by the writer. The main subject matter of the article revolves around the problem of melancholy, the causes of which lie in the writer's experiences and personality, as well as in the external socio-political context characteristic of Central Europe in the second half of the twentieth century. The entire discussion is illuminated by the philosophy of Karl Jaspers.
\end{abstract}

Key words: Bohumil Hrabal, Who I Am, identity, melancholy, Central Europe, Jaspers

Streszczenie: Artykuł jest próbą wpisania utworu Hrabala w autobiograficzny nurt jego prozy. Jest to jednocześnie dekonstrukcja legendy biograficznej pisarza poprzez ponowne nazwanie i zdefiniowanie zabiegów językowych oraz metafor przez niego stosowanych. Główna problematyka artykułu oscyluje wokół zagadnień melancholii, której przyczyny leżą zarówno w doświadczeniach i osobowości Hrabala, jak i w zewnętrznym kontekście społeczno-politycznym charakterystycznym dla Europy Środkowej drugiej połowy XX wieku. Całość rozważań oświetla filozofia szyfrów transcendencji Karla Jaspersa.

Słowa kluczowe: Bohumil Hrabal, Kim jestem, tożsamość, melancholia, Europa Środkowa, Jaspers 
Dziś wiem, że ta moja sinusoida w rzeczywistości jest także sinusoidą mojego narodu, że jestem medium społeczeństwa i środowiska, w którym żyję... A ponieważ od dzieciństwa żyję w Europie Środkowej, ponieważ mieszkam w samym sercu Europy, dopiero teraz $\mathrm{w}$ pełni pojmuję, że zarówno na mnie, jak i na tym moim pisaniu odcisnęły piętno wydarzenia polityczne, a chociaż czasem ich nie akceptuję, muszę $\mathrm{w}$ końcu się z nimi pogodzić, ponieważ są...

B. Hrabal: Odnaleziona Ósemka

\section{Tytułem wstępu}

W roku 1983, w wieku niemal siedemdziesięciu lat, Bohumil Hrabal dokończył jeden ze swoich najważniejszych quasi-autobiograficznych utworów o tytule Kim jestem. Ów niewielki objętościowo tekst nie poddaje się prostej klasyfikacji gatunkowej, nie jest on wspomnieniem, pamiętnikiem, powieścią, nowelą ani klasycznym esejem, choć tytuł tomu, w którym polski czytelnik znajduje ów utwór (Hrabal, Kundera, Havel... Antologia czeskiego eseju1), może to jednoznacznie sugerować. Kim jestem to bogaty w refleksje i konteksty utwór sytuujący się na granicy wyznania, spowiedzi i usprawiedliwienia. Składają się na niego wielokrotnie już przywoływane i tak dobrze znane czytelnikom Hrabala anegdoty z jego młodości i praskiego życia na Libni, przeplatane zapisem dialogów z ważnymi dla pisarza filozofami oraz kryptocytatami zaczerpniętymi z wielkich dzieł literatury światowej.

Polifonia głosów i przemieszanie gatunków mają wyraźny cel autor spogląda na swoje życie $\mathrm{z}$ wielu perspektyw, przegląda się w czyichś oczach i czyichś opowieściach. W latach 80. Hrabal stworzył wiele utworów o charakterze rozrachunkowo-biograficznym. W roku ukończenia Kim jestem powstało również niewielkie opowiadanie Auteczko - takie imię nosił jeden z ukochanych kotów Hrabala, i to właśnie miłość do kotów oraz zbrodnie w jej imię popełniane stały się asumptem do literackiej spowiedzi twórcy. Rok 1984 przyniósł pierwszą część trylogii Wesela $w$ domu, której narratorką jest Pipsi - żona pisarza. Przejęcie kobiecego głosu umożliwiło autorowi ironiczne kreowanie własnego wizerunku. Rok później powstały dwie kolejne części trylogii: Vita nova oraz Przerwy w zabudowie.

${ }^{1}$ Hrabal, Kundera, Havel... Antologia czeskiego eseju. Oprac. J. BALuch. Kraków 2001. 
W latach 80. ukazał się wywiad-rzeka z Hrabalem, który przeprowadził węgierski pisarz László Szigeti, o tytule Drybling Hidegkutiego oraz tom opowiadań Życie bez smokingu z utworami o tematyce metaliterackiej przynoszącej refleksję o warsztacie twórcy. Należy jednocześnie pamiętać, że już w latach 70 . Hrabal napisał kluczowe dla siebie utwory ukazujące jego nymburskie dzieciństwo, a mianowicie Postrzyżyny (1970), Miasteczko, w którym czas się zatrzymał (1973) oraz Taka piękna żałobę (1978).

W przywołanych dziełach Hrabal owocnie wykorzystywał wątki autobiograficzne oraz metaliterackie. Niemal wszystkie teksty czeskiego pisarza - opowiadania, powieści czy utwory na granicy wspomnienia i eseju - wyposażone są w naddatek (auto)biograficzny, bez którego nie sposób analizować i rozważać tej wybitnej twórczości. Tak rozumiane „życiopisarstwo” stanowi fundament, na którym wznosi Hrabal konstrukcję swoich dzieł (a zatem dominują elementy wspomnienia, wyznania, spowiedzi czy wręcz geopoetyckiego przepisywania miejsc, w których żył). Jednocześnie za każdym razem transcenduje on przy tym poza własne doświadczenie, a wręcz wzbogaca je głosami i biografiami innych. Sam zwykł mówić, że nie jest pisarzem, lecz zapisywaczem²:

I ja całe moje pisanie, moje najlepsze pomysły zawdzięczam temu, co usłyszałem, co dostałem. Zostałem wybrany, przemówił do mnie ten szyfr, ten czynnik transcendentalny [...]. Dopiero wtedy jest się naznaczonym, obdarzonym tą łaską przeżywania stanów mistycznych, jest się tym, którym jest, jest się sobą. [...] kiedy wracam do domu, to naraz coś mnie tknie, bo usłyszałem coś, czego wcześniej nie znałem, anegdotę, która wzięła się nie wiadomo skąd, bo tam nie ma autorów ${ }^{3}$.

Przywołane słowa wyraźnie ukazują Hrabalowską filozofię tworzenia, która stała się tematem jego wielu prozatorskich rozważań. Szyfr - czynnik transcendentalny, o którym wspomina pisarz - jest wyrazem wzmożonego zainteresowania filozofią Karla Jaspersa i jego dziełem o tytule Szyfry transcendencji z 1961 roku. Josef Zumr, przyjaciel Hrabala, wspomina, że to właśnie myśl niemieckiego filozofa, obok Ladislava Klímy, Artura Schopenhauera, Laoziego i Rolanda Barthes'a, fascynowała pisarza w latach 80. i stała się

${ }^{2}$ Zob. B. Hrabal: Drybling Hidegkutiego, czyli rozmowy z Hrabalem. Rozmawia László Szigeti. Tłum. A. Kaczorowski. Warszawa 2011, s. 134.

${ }^{3}$ Ibidem, s. 133. 
źródłem inspiracji wielu motywów i fragmentów jego późnej twórczości ${ }^{4}$.

Filozofia Karla Jaspersa, a konkretnie teoria sytuacji granicznej oraz szyfrów transcendencji, umożliwia analizę utworu Kim jestem z dwóch zasadniczych i sprzężonych z sobą perspektyw: życia prywatnego pisarza i jego kondycji psychofizycznej oraz perspektywy polityczno-historycznej związanej z byciem Środkowoeuropejczykiem. I to właśnie tym dwóm problemom poświęcona jest niniejsza analiza.

\section{Wewnętrzny sąd}

Konfesyjny charakter utworu Kim jestem pozwala postawić tezę, że autor zmagał się z wyrzutami sumienia z powodu winy, stanowiącej niezbywalną część jego życia: „Stoję sam przed własnym sądem, a ten mój wewnętrzny sąd jest wielkim przesłuchaniem, jest to jednocześnie oskarżenie i obrona, ja zaś jestem dla siebie prokuratorem i adwokatem" ${ }^{\prime \prime}$. Wewnętrzna walka z własnym sumieniem to po części skutek nieprzystawalności pisarza do opresyjnej zasady rzeczywistości, której jest jednocześnie i świadkiem, i uczestnikiem: „[...] uważam się za świadka, a nie za wyrzut sumienia epoki. [...] Jestem tylko własnym wyrzutem sumienia, na razie" ${ }^{\prime \prime}$. Wewnętrzny sąd wiąże się z uświadomieniem sobie własnej (nie)zawinionej winy, ta z kolei wywołuje u autora stany lękowe i bezsenność: „Nad ranem, kiedy pocę się ze strachu, choć wcale nie wiem dlaczego, zjawiają mi się różne obrazy; niektórych się boję, inne są pozornie kojące" Przypominający spowiedź utwór uznać można zatem za rodzaj skrupulatnie przez pisarza przeprowadzanego samosądu. Warto jednak postawić pytanie, w jakim stopniu elementy wyznania, lęki i myśli samobójcze przeplatają się w nim z fikcją literacką - od której autor bynajmniej nie stroni.

Quasi-autentyczność wyznań Hrabala wiąże się częściowo z językiem, którym posługuje się pisarz. Jego przyjaciele zgodnie twierdzą,

${ }^{4}$ Zob. audycja radiowa poświęcona życiu i twórczości Hrabala, przygotowana przez Miloša Doležala: Nežil jsem nadarmo. A přeci - jsem ztracen!, a emitowana w Český rozhlas. Vltava. https://vltava.rozhlas.cz/nezil-jsem-nadarmo-apreci-jsem-ztracen-5045055 [dostęp: 29.01.2020].

${ }^{5}$ B. Hrabal: Kim jestem. Tłum. A. Jagodziński. W: Hrabal, Kundera, Havel..., s. 5.

${ }^{6}$ Ibidem, s. 3-4.

7 Ibidem, s. 38. 
że miał on fenomenalną pamięć słuchową, którą wykorzystywał w swoim pisarstwie ${ }^{8}$. To jemu zawdzięczamy przeniknięcie hovorovej češtiny, czyli języka mówionego, do świata literatury. Obecność języka ulicy w twórczości literackiej nie jest niewinna - głosy innych zasłyszane w knajpianym gwarze są wyrazem uniwersalnego doświadczenia każdego człowieka: „Cieszyłem się, kiedy to, co zdarzyło się innym, zdarzyło się także mnie, więc chętniej uznawałem za swoje to, co spotykało innych" ${ }^{\prime \prime}$. Zatem pytanie o autentyczność wyznań Hrabala i prawdziwość wydarzeń przedstawionych w utworze Kim jestem jest zasadne tylko wtedy, kiedy doświadczenie indywidualne uznamy jednocześnie za doświadczenie uniwersalne przefiltrowane przez wyobraźnię artystyczną twórcy. Nagromadzenie w niewielkim utworze Kim jestem motywów (akumulace motivü) oraz rotacji (rotace) - czyli sposobu ich łączenia i wprawiania w ruch - ma na celu "wciągnięcie” czytelnika w świat pisarza oscylujący na granicy realizmu i biografii oraz zmyślenia i ironii. Jak sam tłumaczył: „Poruszam się w milieu praskiej ironii, w tym, co przekorne, niedosłowne" ${ }^{\prime \prime 10}$. Tę przekorność i niedosłowność Jerzy Niecikowski nazywa blagierstwem, a utwór Kim jestem automistyfikacją ${ }^{11}$. Leszek Engelking zauważa z kolei, że „Hrabal to pisarz bardzo świadomy, wie, że nawet $\mathrm{w}$ najszczerzej przeżywanym bólu artysta szuka podniety dla swojej sztuki"12. Zatem sztuką jest nie tylko literatura, ale i samo życie - świadomie przekształcane, upiększane i dramatyzowane.

Bohumil Hrabal jest głównym bohaterem swoich utworów, aktorem pierwszego planu rozpisanym na głosy swoich postaci. Można dokonać przewrotnej zamiany i polifonię głosów innych - knajpianego pábení13 - wywieść z wnętrza samego autora, który nie tylko zapisuje to, co usłyszał, ale kreuje to, co mówi drugi człowiek. Gdyby

${ }^{8}$ Zob. M. DoležAL: Nežil jsem nadarmo. A přeci-jsem ztracen!...

9 B. Hrabal: Kim jestem..., s. 4.

${ }^{10}$ IDEm: Drybling Hidegkutiego, czyli rozmowy z Hrabalem..., s. 23.

${ }_{11}$ Zob. Bohumil Hrabal. Finezje literackie. Ninateka. https://ninateka.pl/audio/ bohumil-hrabal-finezje-literackie-4-5 [dostęp: 29.01.2020].

${ }^{12}$ L. Engelking: Proces Bohumila Hrabala. W: Idem: Szwejkowie i Don Kichoci. Łódź 2019, s. 147.

13 „Postać »pabitela« stała się ucieleśnieniem estetyki słowa Hrabala i typu uprawianej przez niego narracji, stylizowanej na język mówiony. Jego pierwowzorem był wuj Hrabala, Josef Hrabal, występujący w jego prozie jako »wujek Pepin«, ale z czasem samego Hrabala nazywali krytycy »największym pabitelem czeskiej literatury«, a sposób jego opowiadania - "pabieniem«". J. BALUCH, P. Gierowsкi: Czesko-polski słownik terminów literackich. Warszawa 2016, s. 273. 
przyjać strategię niedowierzania Hrabalowi, podważania jego tez, zwłaszcza w tych utworach, które uznaje się za autobiograficzne, można dojść do konstatacji, że żaden czytelnik ani żaden krytyk nigdy nie uchwycą istoty Hrabalowskiego „kim jestem”. Wskazuje na to już sam początek utworu:

Przez całe życie niechcący kłamałem, bo żyłem w świecie, w którym nie było nic innego prócz kłamstwa, ale na jego końcu można dostrzec światło prawdy. [...] Moje teksty są dla mnie na razie karą za to, że miotam się pomiędzy zbrodnią a nienawiścią, że odkładam definitywnie rozliczenie i wyrok, że trochę stałem się tym, kim zawsze pragnąłem być, poetą przeklętym. [...] więc jestem przynajmniej odważny dzięki temu, że podtrzymuję tekstem i w tekście poczucie własnej winy. A przy tym się drżąco uśmiecham. To jest mój wisielczy humor... ta moja praska ironia ${ }^{14}$.

Na tym polega główny postulat czeskiego pisarza: przeciwstawiać sobie słowa, tworzyć wzajemnie wykluczające się kontaminacje, bezpośredniość wyznania zakrywać ironią, nieścisłościami, jednoczesnym płaczem i śmiechem ${ }^{15}$. Hrabal zderzał z sobą przeciwności, które wzajemnie się warunkują i tylko w oksymoronicznym zestawieniu zyskują nowe znaczenia. Pisarz tego typu zabiegi nazywał ludibrionizmem: „,[...] gdzie byt powstaje z niebytu, a światło z ciemności i na odwrót. To właśnie jest cud, to właśnie ludibrionizm, te przeciwieństwa i kontradykcje, że każde przeciw jest prawdą"16. Pojęcie to zaczerpnął z filozofii Ladislava Klímy ${ }^{17}$, swojego przewodnika intelektualnego, pisarza i myśliciela żyjącego na przełomie

14 B. Hrabal: Kim jestem..., s. 3-6.

15 „Byle co wzrusza mnie do łez. To łzy radości; płaczę ze szczęścia, że coś przeczytałem - bo również literatura doprowadza mnie do łez. [...] Zawsze lubiłem się śmiać, aż mnie skręcało, aż musiałem uważać, żebym nie umarł ze śmiechu". B. Hrabal: Drybling Hidegkutiego, czyli rozmowy z Hrabalem..., s. 112-117.

${ }^{16}$ Ibidem, s. 69-70.

17 Ladislav Klíma główne założenia swojej filozofii rozpisanej w formie anegdot bądź listów do przyjaciela zawarł w tezie ,jestem wolą absolutną", która pieczętowała założenia egodeizmu. Zapiski Klímy były niezwykle neurotyczne, tak jakby sam filozof przyjmując założenia o absolutnej wolności i własnej boskości z tego wynikającej, jednocześnie unicestwiał swój byt i popadał w największą abstrakcję. Hrabala najbardziej fascynowało w Klímie to, że on sam był ucieleśnieniem swojej filozofii, czyniąc z siebie tym samym „poetę przeklętego, który strawił życie na pisaniu i piciu". (B. Hrabal: Drybling Hidegkutiego, czyli rozmowy z Hrabalem..., s. 38). Hrabal, czytając teksty Klímy, odpowiadał sobie na pytanie, dlaczego pisze. 
XIX i XX wieku. Przywołane kontradykcje w praktyce pisarskiej Hrabala są czytelne nie tylko na poziomie treści Kim jestem, ale również $\mathrm{w}$ strukturze tekstu, która przypomina wariację na temat powracających motywów. Część pierwsza utworu stanowi zarys tła społeczno-historycznego współtworzącego tożsamość autora. Utwór otwiera znamienna deklaracja Hrabala: „Nigdy, nawet we śnie, nie przyszła mi do głowy chęć zmieniania wydarzeń politycznych. [...] zawsze chciałem zmienić sam siebie, tego, którego miałem na wyciągnięcie ręki, siebie samego"18. Część drugą natomiast rozpoczyna zakwestionowanie kategorii autentyczności i refleksja nad tym, co oznacza „być samym sobą" i czy jest to w ogóle możliwe:

Oto człowiek, który nie jest sam sobą. [...] Mój mózg jest orzeszkiem Kopciuszka, zamiast szaty mam głowę pełną rupieci, krańcowych sytuacji, katastrof, twarzy innych ludzi, fragmentów zdań, wydarzeń, aż mi z tego wszystkiego szumi i trzaska w głowie. [...] kiedy tak stoję, zmierzyłem przeszłość nie tylko swoją, ale i losy tego narodu, okupowanego teraz przez wojska radzieckie, tak jak przed tysiącem lat przez armie Ottońskie ${ }^{19}$.

Pragnienie Hrabala: „Ja chciałbym tylko zmienić samego siebie, chciałbym sprawić, abym sięgnął niebios, gdzie mógłbym powiedzieć: jestem taki, jaki jestem..."20, okazuje się niemożliwe do spełnienia wyłącznie w życiu empirycznym. Tęsknoty i obawy pisarza korespondują z filozofią egzystencjalną Jaspersa. Według tłumaczki i komentatorki pism niemieckiego filozofa Czesławy Piecuch: "Jaspersa człowiek jest sobą, pytając o Byt, natomiast gdy pytanie to ustaje, zamiera jego życie egzystencjalne, co na gruncie tego myślenia oznacza swoistą zdradę siebie samego" ${ }^{\prime 21}$. Hrabal doskonale zdaje sobie sprawę, że pytanie o „ja" wymaga transcendowania, czyli przekraczania siebie. Przekraczanie siebie to egzystowanie, a człowiek doświadcza go w zetknięciu z sytuacją graniczną. Za sytuacje graniczne uważał zaś Jaspers przypadek, cierpienie, śmierć, walkę oraz winę; wszystkie one są ostateczne, nieuchronne oraz totalne ${ }^{22}$. Próba odpowiedzi na pytanie „kim jestem?” oraz najgłębsze doświadczanie własnej podmiotowości są u swego źródła tragiczne udowadniają ograniczoność natury ludzkiej oraz konieczność po-

\footnotetext{
18 B. Hrabal: Kim jestem..., s. 3.

19 Ibidem, s. 18-19.

${ }^{20}$ Ibidem, s. 4.

${ }^{21}$ C. Piecuch: Metafizyka egzystencjalna Karla Jaspersa. Kraków 2011, s. 9.

${ }^{22}$ Por. ibidem, s. 41.
} 
dejmowania wyborów, które często niosą skutki niezależne od woli i planu człowieka. Kim jestem można uznać zatem za komentarz Hrabala do samego siebie - niejednoznacznego, cierpiącego, owładniętego strachem i wyrzutami sumienia.

W rozmowie z Szigetim Hrabal przejmująco diagnozuje własną kondycję psychiczną:

Ja zawsze na to cierpiałem, na głęboką melancholię, ale ta melancholia jest, o czym dowiadujemy się od pana Jaspersa, kategorią graniczną. [...] Naraz coś się zaczyna dziać, objawia się panu jakaś myśl, której mógł się pan spodziewać tylko będąc pogrążonym w melancholii. [...] Myśl Leibniza o melancholii wiecznej budowy to moja myśl przewodnia. W tej melancholii wiem, że umrę, w tej głębokiej melancholii wiem, że i to niebo gwiaździste runie kiedyś na ziemię, ale pomimo to przychodzi chwila, w której czuję nagle, że wieczność trwa i że ja jestem, że czasem nawet jestem tym, który jest ${ }^{23}$.

Pisarz utożsamia melancholię z Jaspersowskim cierpieniem, które samo w sobie jest sytuacją graniczną (np. w odniesieniu do fizyczności człowieka i odczuwania bólu ${ }^{24}$, oraz które towarzyszy wszystkim pozostałym sytuacjom granicznym. Hrabalowska melancholia jest zatem metaforycznym oknem na Byt, Boga, sens życia. Wiąże się ona $\mathrm{z}$ wcześniej wspomnianym poczuciem niezawinionej winy za bycie człowiekiem, z działaniem w świecie i doświadczeniem śmierci. W latach 80 . i 90. XX wieku zmarły najbliższe osoby pisarza: żona Eliška, brat Břetislav i najlepszy przyjaciel - Karel Maryska. Wówczas nasiliły się u Hrabala bezsenność, stany lękowe i myśli samobójcze. Motyw samobójstwa pojawia się zresztą w jego twórczości niezwykle często; w pierwszej części trylogii autobiograficznej Wesela w domu narrator mówi:

Wie pani, właściwie ta moja pisanina, teraz zaczynam to pojmować, ta moja pisanina także jest taką obroną przed samobójstwem, tą pisaniną jakbym uciekał przed samym sobą i od siebie, zarazem jednak docieram gdzieś do tego: Co ze mnie będzie? Kim byłem i jestem właśnie teraz? ${ }^{25}$

Utwór Kim jestem potraktować można zatem jako oswajanie sytuacji granicznych, jakimi są odejście bliskich oraz świadomość własnej choroby i zbliżającej się śmierci. Istota sytuacji granicznej nie

${ }^{23}$ B. Hrabal: Drybling Hidegkutiego, czyli rozmowy z Hrabalem..., s. 54.

${ }^{24}$ C. Piecuch: Metafizyka egzystencjalna..., s. 77.

${ }^{25}$ B. Hrabal: Wesela $w$ domu. Tłum. P. Godlewski. Warszawa 2010, s. 114-115. 
jest dyskursywna i wymyka się symbolizacji, jednak przeżywanie jej „Wtargnięcia” do życia empirycznego może być łagodzone głębokim nad nią namysłem. By choć częściowo oswoić strach i cierpienie związane z własną starością, Hrabal sięga do wspomnień z dzieciństwa:

I zobaczyłem jeszcze raz ten opustoszały wyciąg na Gruń [...] a ja w tym widzeniu stałem na dole i potem na każdym krzesełku sadzałem samego siebie, od dzieciństwa; najpierw chłopczyka w czerwonym płaszczyku i czerwonym kapeluszu z kogucim piórkiem, po nim chłopca $\mathrm{w}$ stroju marynarskim, potem ucznia w odświętnym ubranku... wszystkie fazy mego życia w ciągu sześćdziesięciu lat sadzałem na wznoszących się ku niebu krzesełkach z numerami [...], a przede wszystkim widziałem, jak do mnie, starca, zbliża się chłopczyk w czerwonym płaszczyku i teraz, kiedy już mogliśmy podać sobie ręce, tylko patrzymy na siebie; tak, to ja, wspinający się na górę, i ja, schodzący po drabinie Jakubowej na dól, na ziemię, i tak oto mija się ze sobą moich sześćdziesiąt lat [...] i kiedy już jako ostatni zeskoczyłem na górze z zabezpieczonego łańcuchem krzesełka, obejrzawszy się zobaczyłem, że moja droga, po której wzniosłem się na niebiosa, jest pusta, ale tam, na dole, zeskoczył teraz chłopiec $\mathrm{w}$ marynarskim stroju i pomachał do mnie swoją czapeczką ${ }^{26}$.

Czy siedemdziesięcioletni Hrabal piszący te słowa i mały chłopiec w czerwonym płaszczyku to ta sama osoba? Czy starzenie się przynosi mądrość, a jeśli tak, to czy mądrość ta jest otwarta na - by sięgnać tu do słownika Jaspersa - prawdę egzystencji? Autor Zbyt głośnej samotności zdaje się odpowiadać na tak postawione pytania twierdząco: „Dzięki temu, że już za późno, zdobywa się prawdę, zawsze więcej wartą od jakiejkolwiek fikcji. [...] Starcy zawsze byli na czele, bo mieli na wyciągnięcie ręki swoją skąpaną $\mathrm{w}$ świetle młodość..."27. Podczas tworzenia Hrabal spoglądał wstecz na własne życie i mierzył się z pytaniem o człowieczeństwo i życie po śmierci. Jednocześnie $\mathrm{w}$ swoich utworach wykonywał gest zaczarowania otaczającej go rzeczywistości. Najlepiej wyraża to utrwalone już w kulturze zdanie wypowiadane przez stryja pisarza - Pepina: „Ten świat jest opętańczo piękny, nie dlatego, że jest, ale że ja go tak widzę" ${ }^{\prime 28}$. A co naprawdę widział wokół siebie Hrabal?

${ }^{26}$ B. Hrabal: Kim jestem..., s. 41.

27 Ibidem, s. 9.

28 Zob. T. Mazal: Spisovatel Bohumil Hrabal. Praha 2004, s. 333. Tu i dalej, o ile nie zaznaczono inaczej, cytaty czeskie w przekładzie na język polski - M.B. 


\section{Fen w sercu Europy}

W Kim jestem Hrabal wspomina kolejne etapy swojego życia: wczesne dzieciństwo, które spędził z babcią i dziadkiem na ulicy Balbínovej w Brnie, szkołę w Nymburku, towarzyszenie ojcu podczas obowiązków służbowych w gospodach, późniejszą pracę w roli dyżurnego ruchu na kolei $\mathrm{w}$ Kostomlatach, robotnika w hucie Poldi w Kladnie czy pakowacza makulatury w Pradze. Bez tych doświadczeń nie powstałyby najwybitniejsze bodaj utwory pisarza - Pociagi pod specjalnym nadzorem oraz Zbyt głośna samotność. Ten ostatni zresztą jest również świadectwem terroru „normalizacji”, który ogarnął Czechosłowację w latach 70. Prywatny wymiar tych przeżyć Hrabal opisał w Takiej pięknej żałobie, a oksymoroniczny tytuł zbioru opowiadań po raz kolejny wskazuje na przewrotną strategię pisarza, który odchodzenie czasów i wspomnień z nimi związanych opisuje za pomocą idyllicznych obrazów. W Kim jestem natomiast migawki z dzieciństwa i młodości przeplatają się z losem Czechosłowacji: „[...] i właściwie to jestem ja, tak jak ja jestem losem Hradczan, losem kraju, który jest tak piękny, że potężniejsi sąsiedzi zawsze go zdobywali przemocą albo skrwawioną przyjaźnią" ${ }^{\prime 29}$.

Polifonia $\mathrm{w}$ dziele Hrabala nie ogranicza się jedynie do przywołania słów przyjaciół z gospód czy rodziny pisarza - Hrabal wsłuchuje się również w głos swojej ojczyzny, której historię rozważa w perspektywie długiego trwania - od powstania narodu do czasów współczesnych. Utwór Kim jestem uznać można za świadectwo społeczno-polityczne powstałe $\mathrm{w}$ trakcie największych napięć między pisarzem i władzą komunistyczną w Czechosłowacji. Tomaš Mazal poświęcił temu problemowi cały rozdział biografii Hrabala zatytułowany Stóg siana (Stoh slámy) ${ }^{30}$. Autor Pociagów pod specjalnym nadzorem był pisarzem dwuobiegowym: część jego dzieł ukazywała się $\mathrm{w}$ oficjalnych wydawnictwach państwowych, jednak większość krążyła w samizdacie oraz trafiała do wydawnictw emigracyjnych (m.in. do Sixty-Eight Publishers prowadzonego przez małżeństwo Škvoreckich w Kanadzie). W 1976 roku Hrabal skończył pisać Zbyt głośna samotność - jak sam twierdził, swój najważniejszy utwór ${ }^{31}$.

29 B. Hrabal: Kim jestem..., s. 19-20.

${ }^{30}$ Znana jest historia ukrywania się Hrabala w stogu siana w Kersku przed śledzącymi go agentami StB oraz członkami partii komunistycznej.

31 "Zbyt głośna samotność, jeśli w ogóle jestem człowiekiem dojrzałym, to szczyt mojej dojrzałości. [...] Bałem się go, a kiedy boję się własnego tekstu, to znaczy, że jest on co najmniej dobry". B. Hrabal: Drybling Hidegkutiego, czyli rozmowy z Hrabalem..., s. 108-109. 
Jego opublikowanie było dla pisarza priorytetem, dlatego rok wcześniej w reżimowym tygodniku „Tvorba” ukazał się, jak określił go Aleksander Kaczorowski, "serwilistyczny wywiad z Bohumilem Hrabalem"32. Wywołał on skrajne reakcje wśród krytyków i czytelników pisarza, grupa młodych ludzi spaliła jego książki na Kampie w Pradze. Sam pisarz nigdy nie kolaborował z władzą, chciał jedynie uniknąć emigracji. Mazal przypomina komentarz Hrabala pochodzący z wywiadu udzielonego w 1990 roku:

Jak ze mną pogrywano i pomalutku, ale systematycznie męczono przez dostojnych oficerów naszej jakże humanitarnej służby bezpieczeństwa... To należy do praw i obowiązków obywatela, chociaż w konstytucji nic o tym nie ma, ale kto z moich przyjaciół był i jest wrażliwy, a nawet delikatny, musi wybrać... emigrację... a ja emigrowałem tutaj, do tej gospody na przykład... I, moja droga duńska pani, jak ja się strasznie bałem i jak do dzisiaj się strasznie boję ${ }^{33}$.

Złe samopoczucie było $w$ znacznej mierze powodowane czynnikami zewnętrznymi, a konkretnie sytuacją polityczną, która zdeterminowała XX-wieczną historię Czechosłowacji - samego serca Europy. Bardzo trafnie skomentował to Tomaš Mazal: Hrabal urodził się jako obywatel monarchii austro-węgierskiej na Morawach, a po I wojnie światowej dorastał w rodzącej się Pierwszej Republice Czechosłowackiej. II wojna światowa przyniosła kolejną zmianę na politycznej mapie Europy i w ten sposób pisarz został obywatelem Protektoratu Czech i Moraw, a po wyzwoleniu przez Armię Czerwoną - ponownie Czechosłowacji. Jego dorosłość przypadała na rządy komunistów: „socjalizm z ludzką twarzą”, który przyniosła Praska Wiosna oraz jej tragiczne konsekwencje trwające dwadzieścia kolejnych lat. Kiedy Hrabal doczekał się utworzenia demokratycznej Republiki Czeskiej, był już starcem, „a do grobu zamiast Nagrody Nobla w dziedzinie literatury, do której był nominowany, zabrał ze

32 A. Kaczorowski: Hrabal. Słodka apokalipsa. Wołowiec 2016, s. 243.

33 "Jak jesem býval předváděn a jak jsem býval pomalinku ale systematicky mučinkán dstojníky našeho humanního esenbé... to patří k občanským právům a povinnostem, o tom sice není nic v ústavě, ale kdo byl a je z mých prátel citlivý, dokonce i háklivý, tak musí volit... emigraci... a já jsem emigroval sem, do třeba téhle hospody... A, milá moje dánská dámo, jak já jsem se hrozně bával a jak já se i dneska hrozně bojím!". T. Mazal: Spisovatel..., s. 358. 
sobą - oprócz różnych zagranicznych i krajowych nagród - Państwową Nagrodę im. Klementa Gottwalda" ${ }^{34}$.

Z czasem Hrabal coraz rzadziej uciekał się do fikcji, zaś jego utwory - choć przetworzone przez wyobraźnię autora - odbijały idee i wydarzenia rodzące się w jego ojczyźnie ${ }^{35}$. Czytamy w Kim jestem:

[...] jak powiada Jakob Boehme - człowiek nie może oderwać się od swojej epoki. Ja też się od niej nie oderwałem, bo nie oderwał się od niej ani Beethoven [...], ani Rousseau, ani Herder i Hegel. W końcu jestem przecież homo politicus z tym pewnym odchyleniem, które stanowi korzenie tego kraju, z tą pewną ironią, która nie przeciw, ale $\mathrm{w}$ dialektyce uznaje politykę naszej ograniczonej suwerenności, ale przy tym z zachowaniem melancholii podmiotu, który swym cienkim głosikiem próbuje się wtrącić do rozmowy. Myślę, że mój modus vivendi we współczesnym społeczeństwie nigdy nie jest $\mathrm{w}$ zasadzie przeciw, ponieważ wiem, gdzie i z kim żyję; to, o czym chętnie mówię, że każda nowa epoka, kiedy się zaczyna, to ludzie tacy jak ja znajdują się wśród drzazg pnia, połamanego przez historię, która nie pragnie kontynuować, lecz zbudować od początku całkiem inny model życia publicznego i prywatnego, żeby po niemal dwóch tysiącleciach epoki chrześcijańskiej zacząć swoją epokę, opartą na przeciwnych znakach, na odwrotnej skali wartości ekonomii, a więc i kultury. A ja i mnie podobni musimy znaleźć modus vivendi właśnie wśród drzazg tego złamania... ${ }^{36}$

Hrabal wyraźnie odcinał się od modelu państwa i polityki tworzonej przez komunistów, a zarazem to właśnie ona w ogromnej mierze determinowała jego proces twórczy, życie prywatne i publiczne. Jednak, paradoksalnie, pisarz wykreował swoją legendę na świadomie budowanym outsiderstwie i przebywaniu na uboczu oficjalnego biegu zdarzeń. Hrabalowskie modus vivendi to pisanie i czerpanie z upadku - swojego oraz epoki - ożywczych, twórczych soków. Jego późna twórczość charakteryzuje się coraz wyraźniejszym zamiłowaniem do autentyzmu, a na pierwszy plan wysuwa się sam autor ${ }^{37}$. Pisarz zadawał sobie pytanie o powinności twórcy i rolę literatury,

34 „Do hrobu si namísto Nobelovy ceny za literaturu, na niž byl navrhován, kromě rozličných zahraničních prestižních cen i domácích řádů odnesl Státní cenu Klementa Gottwalda!". T. MAzaL: Spisovatel..., s. 333.

35 Zob. B. Hrabal: Kim jestem..., s. 35.

${ }^{36}$ Ibidem, s. 36.

37 Zob. L. Engelking: Proces Bohumila Hrabala..., s. 148. 
uwikłanej w środkowoeuropejski nadmiar historii. Kim jestem stanowi szczególne odbicie nastroju epoki, który Hrabal wyraża za pomocą genialnej metafory wiatru samobójców. Jego zdaniem już samo geograficzne położenie Czech - w środku Europy - potęguje doznanie sytuacji granicznych: cierpienia, poczucia (nie)zawinionej winy i zbliżającej się śmierci:

Fen wieje w tym kraju nie tylko czterokrotnie, o każdej porze roku, lecz przez cały rok, zalew stresowych sytuacji bez szans na adaptację, błotko banałów. [...] a kiedy nadchodzi fen, na wapieniu ludzkie duszyczki drżą i dygoczą jak liście na wietrze, kto chce uratować się przed fenem i samobójstwem, a nie ma już siły, żeby przez cały tydzień upijać się mocnym piwem, powinien natychmiast pędzić na granit, za Ratyzbonę; tam wrażliwy człowiek jest bezpieczny. Ale ja żyję w kraju, gdzie stale wieje fen, gdzie sytuacje stresowe nie znajdują ukojenia. [...] Mój wieczny fen, mój wieczny splin, moja wieczna chandra, że znów coś przeskrobałem, że kogoś zabiłem, że zasłużyłem na najwyższą karę, choć jestem niewinny jak lilia... ${ }^{38}$

Metafora kraju wystawionego na zabójcze podmuchy wiatru koreluje z metaforą niczym nieosłoniętego serca Europy, skazanego na ciągłe porywy, emocjonalną sinusoidę i niepokój. Hrabal - mistrz łączenia obrazów - myślał za pomocą metafor. Przyjaciele pisarza mówili o nim jako o prawdziwym meteopacie, który reagował na każdą, nawet najmniejszą zmianę pogody. Czynniki atmosferyczne stanowiły też dla niego metaforę „czynników politycznych”, niedających nadziei na przejaśnienie. Inną metaforą, po którą Hrabal chętnie sięgał, jest pępek świata zobaczony jako zielona kropka, którą tworzą koncentryczne kręgi na kapeluszu rydza: „Ten rydz i koncentryczne zielone kręgi, ta zielona kropka pośrodku rudego kapelusza, ten omfalos, pępek świata, dzięki któremu można się cofać w przeszłość aż do gładkiego brzucha pramatki Ewy..."39. Obie metafory, choć wyobrażeniowo odmienne, dotykają w gruncie rzeczy podobnego problemu - myślenia o centrum w kategoriach nie tylko przestrzenno-geograficznych, ale i filozoficznych. Życie w środku Europy przypomina drogę nie tyle bez wyjścia i dobrych rozwiązań, ile zmusza do ciągłego powracania w głąb siebie.

Autor Zbyt głośnej samotności udowadnia, że mierzenie się z emocjami nieznajdującymi ukojenia jest $\mathrm{z}$ jednej strony tragiczne, bo

${ }^{38}$ B. Hrabal: Kim jestem..., s. 30-31.

${ }^{39}$ Ibidem, s. 12. 
skutkuje myślami samobójczymi, depresją i społeczną izolacją, a z drugiej - umożliwia kontakt z tym, co Jaspers nazwał szyframi transcendencji.

Te szyfry, które są znakami wyższej rzeczywistości, szyfry, które prowadzą do logosu, Bóg, zło i dobro, to wszystko, co prowadzi $\mathrm{ku}$ transcendencji, czy nawet ku metafizyce, wszystko to można poznać jedynie na drodze łaski. [...] Według Jaspersa tajemnica szyfrów polega na tym, że to one przemawiają do nas, a nie my do nich, to one nas wybierają i na tym właśnie polega łaska ${ }^{40}$.

W myśleniu Jaspersa szyfr, w odróżnieniu od symbolu ${ }^{41}$, nie poddaje się wyjaśnieniu, a jego doświadczenie jest wyłącznie jednostkowe i indywidualne. To przez niego przemawia transcendencja. Dla Hrabala uobecniała się ona głównie w opowieści - czyjejś i jego własnej, w postaci literatury. Według Jaspersa sens życia człowieka polega na nawiązaniu więzi z samym sobą, na odpowiadaniu na pytanie: kim jestem? ${ }^{42}$ To fundamentalne pytanie stawiane przez Hrabala w niemal każdym dziele jest tak naprawdę nieustannie wyrażaną wątpliwością dotyczącą samowiedzy - poznania siebie, które wykracza poza rozum. Związany z jednostkowością człowieka czynnik egzystencjalny oraz czynnik metafizyczny - związany z doświadczeniem bytu - składają się na szyfr transcendencji. Istotą ludzkiego doświadczenia jest pogodzenie się z niezgłębioną tajemnicą życia, zwłaszcza że wszelkie próby jej odkrycia czy też rozszyfrowania grożą utratą tajemnicy, czyli łączności z tym, co następuje po śmierci. W eseju Odnaleziona Ósemka Hrabal naszkicował swój portret z poziomą ósemką nad głową:

[...] jestem tym, którym jestem, starszym panem, spacerującym w kapelusiku, nad którym unosi się leżąca ósemka, szyfr i znak nieskończoności, zabawna, wesoła ósemka, szyfr, w którym wy-

40 B. Hrabal: Drybling Hidegkutiego, czyli rozmowy z Hrabalem..., s. 122.

${ }^{41}$ Dla Jaspersa rzeczy widzialne są symbolami rzeczy niewidzialnych (jest to relacja egzystencji z transcendencją). Czesława Piecuch tak definiuje pojęcie symbolu w rozumieniu filozofa: „Nasuwa się pewne podobieństwo szyfru do symbolu. Wszakże szyfr rozpatrywany jako symbol jest inny niż pozostałe symbole, gdyż cechuje go szczególna właściwość, mianowicie, co podkreśla Jaspers, szyfr nie pozwala się rozszyfrować. Czyli należy to rozumieć tak, że w wypadku szyfru nie można go rozdzielać, to znaczy nie można oddzielać samego symbolu od tego, co on miałby symbolizować, jak to się czyni w przypadku innych symboli". EAdem: Metafizyka egzystencjalna..., s. 238.

42 Por. K. Jaspers: Szyfry transcendencji. Tłum. C. Piecuch. Toruń 1995, s. 18-19. 
raża się wieczny duch materii, świat realny i świat snu, rezolutna ósemka, zawiązany na kokardkę początek i koniec świata, wypaczona sinusoida przypływu i odpływu, form skostniałych i takich, w które tchnięto życie... unosząca się nad głową ósemka, która daje mi pewność, że nawet gwieździste niebo kiedyś zgaśnie, żeby wszystko zaczęło się na nowo... ${ }^{43}$

Perspektywa spojrzenia z góry, którą przyjmuje pisarz również (a może przede wszystkim) w stosunku do własnej osoby, przypomina spojrzenie Boga. Ósemka porównana do szyfru jest tak naprawdę uobecnieniem transcendencji, która nie daje się zgłębić, ale umożliwia drogę do pełnej samowiedzy. Ta z kolei pociąga za sobą refleksję o coraz bliższym życiu po śmierci.

\section{Droga do światła}

Początek lat 90. nie przyniósł pisarzowi upragnionego spokoju. Aksamitna rewolucja i rozpoczynająca się demokratyzacja Czechosłowacji, a później Republiki Czeskiej, zbiegła się w czasie z pogarszającym się stanem zdrowia Hrabala, złą kondycją psychiczną i nadmierną wrażliwością emocjonalną. Autor Zbyt głośnej samotności istotnie nie potrafił znaleźć ukojenia; w sylwestra 1989 roku pisał: „[...] tymczasem ja, choć powinienem być chłopem na schwał, cierpię na niewytłumaczalną depresję, w tym roku spędziłem pięć tygodni w klinice neurologicznej, nie tylko z bezwładem nóg, ale i całej duszy..."44. Dzieła pisarza nareszcie mogły być sukcesywnie wydawane i tłumaczone, jednak największą popularność i szacunek Hrabal zdobył nie w swojej ojczyźnie, a za granicą. Tomaš Mazal zauważa, że „wielu pisarzy tworzących w samizdacie, wielu pisarzy emigracyjnych albo pisarzy przed debiutem wydawniczym, po cichu, ale dobitnie wyrażało opinię: dość Hrabala! Wychodził za komunistów, chodził na ustępstwa władzy, usługiwał jej i dostał za to nagrodę zasłużonego artysty"45. Reguły wolnego rynku, kapitalizm

${ }^{43}$ B. Hrabal: Odnaleziona Ósemka. Tłum. A. Kaczarowski. W: B. Hrabal: Piękna rupieciarnia. Wołowiec 2019, s. 99.

${ }^{44}$ B. Hrabal: Wspomnienie pięknego sylwestra. Tłum. A. Kaczorowski. W: Idem: Piękna rupieciarnia..., s. 165.

45 „Nejeden ze spisovatelů domácího samizdatu, nejeden z exilových spisovatelů nebo spisovatelů ještě bez díla potichu, ale přeci zřetelně vyslovil názor: Dosti Hrabala! Vycházel za komunistů, dělal jim ústupky, sloužil jim a dostal za to zasloužilého umělce". T. MazaL: Spisovatel..., s. 358. 
i wolność słowa przyczyniły się do (nad)produkcji potransformacyjnej literatury. Oskarżenia rodzimych twórców kierowane w stronę Hrabala wyrażały długo skrywane resentymenty, a sam pisarz czuł się jeszcze bardziej wyobcowany i zasypany "drzazgami” zmieniającej się epoki. W 1995 roku podczas podróży do Włoch Hrabal wyraźnie zdefiniował - trochę na przekór swoim oponentom - czym powinna być dobra literatura: „Wielka literatura może powstać tylko w wyniku zmiany miejsc transcendentalnych. A te transcendentalne miejsca jeszcze nie zmieniły się na tyle, żeby odzwierciadlało je powstanie przyzwoitej literatury"46. „Transcendentalne miejsca” a więc umiejętność odczytywania szyfrów - oraz zrozumienie dziejów historii to dwa wielkie wyzwania, ale i dwa cele literatury, która niosłaby światło naznaczonemu melancholią sercu Europy.

Sam Hrabal coraz częściej rozważał popełnienie samobójstwa, które według Jaspersa wynika z niezgody na działanie losu, który determinuje warunki życia jednostki. Może ono również być efektem postawy rezygnacji z życia wypełnionego cierpieniem. Temat śmierci samobójczej został $\mathrm{w}$ twórczości pisarza dwojako zobrazowany: po pierwsze był to skok z piątego piętra, po drugie natomiast stan przejścia - wychodzenie z mroku do światła. W 1989 roku w utworze Zaczarowany flet Hrabal pisał:

Sprawia mi ból już całe miasto, w którym mieszkam, sprawia mi ból już cały świat, bo nad ranem przychodzą do mnie istoty, które nie są mi znane, ale wprost przeciwnie, które $\mathrm{z}$ wolna i nieuchronnie wspinają się po ruchomych schodach mojej duszy, ostrzejsze stają się nie tylko ich twarze, ale pewne przeraźliwe wydarzenia, tak jak portret, tak jak film, dokumentalny film nie tylko o tym, jak się kiedyś do szaleństwa kochałem, ale także i o tym, jak zawiodłem. [...] Rano samobójstwo, przed południem praca, w południe obiad w stołówce, po południu jeszcze trochę tej harówy, a potem jest tutaj, w „Barwince”, „Zielonym Laboratorium”, i pije jedno piwo za drugim, w jednym ciągu, aż po ten ostatni kufel, i tak do wieczora ${ }^{47}$.

Hrabal przyznawał jednocześnie, że wielokrotnie rozważał skok z piątego piętra, tak jak przed nim myśleli o tym Franz Kafka czy

46 „Velká literatura může vzniknout jen změnou transcendentálních míst. A ta transcendentální místa ještě nebyla natolik změněná, aby odrazem mohla vzniknout literatura jako taková". Ibidem, s. 359.

47 B. Hrabal: Zaczarowany flet. Tłum. A. Czcibor-Piotrowski. Warszawa 1991, s. 5-6. 
Reiner Maria Rilke. Obsesja zakończenia życia wiązała się z filozofią nieśmiertelności, którą autor Auteczka szkicował na kartach swoich utworów. Dla pisarza każdy koniec był zarazem nowym początkiem:

Jestem człowiekiem, który gdy patrzy za siebie, na swój sławny żywot, który tak bardzo przeciekł mu między palcami, wypełnia się wiarą, że istnieje życie wieczne. [...] To życie wieczne nie jest niczym innym niż zatrważająco piękną jednostajnością, w której odgrywane są wciąż te same katarynkowe walczyki... Śmierć staje się wtedy czymś, co już mnie nie dotyczy, bo jest przyjemną granicą; wystarczy tylko pochylić głowę i wejść tam, skąd wyszliśmy w chwili narodzin. Każdego dnia, kiedy spotykam się z możliwością śmierci, staję bardzo blisko słodkiej tajemnicy, za którą znajduje się królestwo światła. Nie unikam już niebezpieczeństwa śmierci, nie przyjmuję go do wiadomości, bo już się nie boję. Nie pragnę niczego więcej niż tkwić w niewoli światła ${ }^{48}$.

Hrabal sam stworzył najpiękniejszą metaforę przejścia z mroku życia do światła, która przybrała formę rzeźby na rodzinnym grobie w Hradištku, niedaleko Nymburka i Kerska. Rzeźba ta jest interpretacją jego ulubionego obrazu Wizje zaświatów autorstwa Hieronima Boscha. Dzieło malarza przedstawia zielonkawy tunel, przez który przelatują ludzie prowadzeni przez anioły - prosto do światła. W lutym 1997 roku pisarz wypadł ze szpitalnego okna w Pradze. Według oficjalnego komunikatu policji był to nieszczęśliwy wypadek. Według przyjaciół (i taką też wersję przedstawia Mazal) - rozważane od lat samobójstwo. Ta ostatnia karta w biografii-powieści Hrabala zawiera niedopowiedzenie. Dogłębnie wyraża ono tajemnicę życia i śmierci, stale obecną $\mathrm{w}$ stawianym sobie przez pisarza pytaniu kim jestem? Tajemnica ta kryje się w jego życiopisarstwie, które domaga się ciągle nowych czytelników i interpretatorów, rejestrującym los artysty determinowany przez nadmiar środkowoeuropejskiej historii. Ostatecznie sam pisarz stawia przed czytelnikami niełatwe zadanie mierzenia się z egzystencjalnym i szukającym kontaktu z transcendencją pytaniem: „kim jestem?”.

\section{Bibliografia}

Audycja radiowa poświęcona życiu i twórczości Hrabala przygotowana przez Miloša Doležala: Nežil jsem nadarmo. A přeci - jsem ztracen! Český rozhlas.

${ }^{48}$ B. Hrabal: Kim jestem..., s. 8. 
Vltava. https://vltava.rozhlas.cz/nezil-jsem-nadarmo-a-preci-jsem-ztracen-50 45055 [dostęp: 29.01.2020].

Baluch J., Gierowski P.: Czesko-polski słownik terminów literackich. Warszawa 2016. Bohumil Hrabal. Finezje literackie. Ninateka. https://ninateka.pl/audio/bohumil-hrabal-finezje-literackie-4-5 [dostęp: 29.01.2020].

Engelking L.: Proces Bohumila Hrabala. W: Idem: Szwejkowie i Don Kichoci. Łódź 2019, s. 144-148.

Hrabal B.: Drybling Hidegkutiego, czyli rozmowy z Hrabalem. Rozmawia László Szigeti. Tłum. A. Kaczorowsкi. Warszawa 2011.

Hrabal B.: Kim jestem. W: Hrabal, Kundera, Havel... Antologia czeskiego eseju. Oprac. J. Baluch. Kraków 2001, s. 1-33.

Hrabal B.: Miasteczko, w którym czas się zatrzymat. Tłum. P. Godlewski. Warszawa 2014.

Hrabal B.: Odnaleziona Ósemka. Tłum. A. Kaczorowski. W: B. Hrabal: Piękna rupieciarnia. Wołowiec 2019, s. 89-99.

Hrabal B.: Przerwy. Tłum. P. Godlewski. Warszawa 2011.

Hrabal B.: Wesela w domu. Tłum. P. Godlewski. Warszawa 2010.

Hrabal B.: Wspomnienie pięknego sylwestra. Tłum. A. Kaczorowski. W: B. Hrabal: Piękna rupieciarnia. Wołowiec 2019, s. 163-168.

Hrabal B.: Zaczarowany flet. Tłum. A. Czcibor-Piotrowski. Warszawa 1991.

Hrabal B.: Życie bez smokingu. Tłum. A. Babuchowski, A. Kaczorowski, J. StacHowsкi. Warszawa 2011.

Hrabal, Kundera, Havel... Antologia czeskiego eseju. Oprac. J. Baluch. Kraków 2001. Jaspers K.: Szyfry transcendencji. Tłum. C. Piecuch. Toruń 1995.

Kaczorowski A.: Hrabal. Słodka apokalipsa. Wołowiec 2016.

KLíma L.: Jestem wola absolutna. Tłum. K. MrówKA. Kraków 2009.

Mazal T.: Spisovatel Bohumil Hrabal. Praha 2004.

Piecuch C.: Metafizyka egzystencjalna Karla Jaspersa. Kraków 2011.

Magdalena Brodacka - polonistka i bohemistka, doktorantka na Wydziale Polonistyki Uniwersytetu Jagiellońskiego. Przygotowuje rozprawę poświęconą środkowoeuropejskiej tożsamości we współczesnej literaturze polskiej i czeskiej. Stypendystka Józef Tischner Junior Visiting Fellowhsip w Instytucie Nauk o Człowieku w Wiedniu; laureatka konkursu o rezydencję im. Marii i Kazimierza Brandysów w Międzynarodowym Centrum Dialogu w Krasnogrudzie.

e-mail: magdalenabrodacka@gmail.com 